\title{
VIETNAM AND JOINT DEVELOPMENT IN THE GULF OF THAILAND
}

Nguyen Hong Thao*

\section{INTRODUCTION}

The United Nations Convention on the Law of the Sea (UNCLOS) came into force on 16 November 1994, creating a new juridical order for the sea, including a new partition of natural resources. The twenty-first century will continue to be an era of maritime delimitation settlements. More than 400 maritime boundaries must be defined, one third of which have been determined by bilateral agreements or by jurisprudence. ${ }^{1}$ The South China Sea, with twenty maritime disputes, is one of the most prominent regions in the world in this respect.

The Gulf of Thailand is characterized by a slow process of maritime delineation, as is the South China Sea. There are several reasons for this. First, political disagreements hamper countries from smoothly reaching an agreement. Secondly, the region has been profoundly affected by its colonial experience and the interpretation of colonial treaties. Cambodia and Thailand have disagreed over the interpretation of the Franco-Thai treaty of 1907 concerning the attribution of the Island of Koh Kut. Vietnam and Cambodia do not share a common position on the role of the Brevie line in their mutual relationship. ${ }^{2}$ Thirdly, there are many islands and islets in the region. While the maritime disputes in Asia concentrate mostly on the aspect of sovereignty

\footnotetext{
* Faculty of Law, University of Hanoi, Vietnam.

Mailing address: 58 Nguyen Du, Hanoi, Vietnam; <thaonh@vista.gov.vn>

The author would like to thank Professor JON M.VAN DYKE at the William S.Richardson School of Law, University of Hawaii at Manoa for providing comment and assistance during the preparation of this article.

The views presented in this article are not necessarily those of any Vietnamese official.

1 R.R.CHURCHILL, "Joint development zones: international legal issues", in HAZEL FOX (Ed.), Joint development of offshore oil and gas, Vol.2 (The British Institute of International and Comparative Law, 1990) 56.

2 J.R.V.PRESCOTT, The Gulf of Thailand: maritime limits to conflict and cooperation (Malaysian Institute of Maritime Affairs (MIMA), Kuala Lumpur, Malaysia, 1998) 9-11.
} 
over islands, ${ }^{3}$ the maritime disputes in the Gulf of Thailand deal principally with the question of the existence of islands on the delimitation of maritime territories. $^{4}$

Delimitation in the Gulf is not easy. The confrontation between two blocs in the recent past (Indochina and ASEAN, the civil war in Cambodia) prevented the interested parties from making compromises in their efforts to achieve the final and definitive boundary delimitation. In their quest to settle disputes peacefully and exploit natural resources without prejudice to the final delimitation, there is a tendency for the interested parties to enter into provisional arrangements, such as joint development. On 21 February 1979 a Memorandum of Understanding (MOU) on joint development was concluded between Thailand and Malaysia. An agreement on Vietnamese-Cambodian historic waters, concluded on 7 July 1982 in Ho Chi Minh City, put a maritime area under a joint utilization regime. ${ }^{5}$ Before concluding an agreement on their maritime boundary in August 1997, Thailand and Vietnam had also considered the possibility of a regime of joint development for the area of overlap. ${ }^{6}$ Later, Vietnam and Malaysia in their Memorandum of Understanding of 5 June 1992 agreed on applying a joint exploitation regime for a "defined area". In 1999, Vietnam, Thailand and Malaysia agreed in principle on a regime of joint development for a small area of overlap. When the tripartite accord becomes effective, the Gulf will be the first region under

${ }^{3}$ Kuril Islands (Russia-Japan); Takeshima Island (Japan-South Korea); Senkaku Islands (JapanChina-Taiwan); Paracel Islands (Vietnam-China); Spratly Islands (Vietnam, China, Taiwan, Malaysia and Philippines).

4 NGUYEN HONG THAO, Le Vietnam face aux problèmes de l'extension maritime dans la mer de Chine méridionale (thesis, Paris I, 1996) 402-428.

5 Art.3 of the Agreement reads, inter alia: "Pending the settlement of the maritime border between the two States in the historical waters ...

- Patrolling and surveillance in these territorial waters will be conducted jointly by the two sides. - The local population will continue to conduct their fishing operations and the catch of other sea products in this zone according to the habits that have existed so far.

- The exploitation of natural resources in this zone will be decided by common agreement".

6 The Protocol of the first meeting of the Thai-Vietnamese Joint Committee on culture, economic, science and technique cooperation in October 1991 contained the following points:

"(a) both sides should cooperate in defining the limits of the maritime zones claimed by the two countries;

(b) both sides should try to delimit the maritime boundary in the overlapping area between the two countries, and

(c) such delimitation should not include the overlapping zones which are also claimed by any third country.

Both sides also agreed that, pending such delimitation, no development activities or concessions in the area of overlap should be assigned or awarded to any operator. The two sides informed each other that there are no development activities or concessions in the area claimed by Vietnam which overlaps the Joint Development Area between Thailand and Malaysia.

In this context, the Thai side proposed that failing the attempt in (b) the two sides might consider implementing the Thai concept of joint development area". 
a multilateral agreement on joint development. In fact, the region holds a most advanced position in the world as far as joint development models are concerned. ${ }^{7}$

Three points arise in such a context: Why is this model to be preferred in the Gulf where Vietnam is mostly involved? What are the factors that have caused the joint development agreement to become successful? What lessons can be drawn from this experience? This paper will deal with these questions in three sections:

1. The situation in the Gulf

2. Comparison between the Thai-Malaysian MOU of 1979 and the Vietnamese-Malaysian MOU of 1992

3. From MOU 1979 to MOU 1992: factors contributing to success in an agreement of joint development.

\section{THE SITUATION IN THE GULF}

The Gulf of Thailand is characterized by a pattern of overlapping areas: areas claimed by Thailand, Cambodia and Vietnam, by Thailand and Vietnam, by Thailand and Cambodia, and by Thailand and Cambodia, while the tripartite Thai-Malaysian-Vietnamese joint development area overlaps the Vietnamese-Malaysian "defined area". Moreover, between June 1971 and May 1973 South Vietnam, Cambodia and Thailand made respective unilateral claims over the continental shelf in the Gulf of Thailand. ${ }^{8}$

Up to now, three agreements on maritime delimitation in the Gulf have been concluded: two between Malaysia and Thailand, ${ }^{9}$ and a third between Vietnam and Thailand. ${ }^{10}$ The coastal states in the Gulf have usually applied the method of the "median line" in drawing their unilateral claims, but they have different views on the effect of the existence of islands on such delimitation. Since 1972, Thailand and Malaysia have agreed on a limit of 29 miles measured from the edge of the coast into the sea; however, the two sides disagreed on the effect of the islet of Ko Losin on the delimitation. The Thai

\footnotetext{
${ }^{7}$ From 15 cases of areas under a joint development regime in the world, three are located in the Gulf of Thailand.\{Besides, the Cambodia-Vietnam historic water in the gulf of Thailand can be considered primary as the forth joint development area\}

8 South Vietnam promulgated the outer limits of its continental shelf on 9 June 1971, the Thai proclamation on the limits of its continental shelf was made on 18 May 1973, and the Malaysian map showing the outer limits of its continental shelf was published on 21 December 1979.

9 Treaty relating to the delimitation of the territorial seas of the two countries and Memorandum of Understanding on the delimitation of the continental shelf boundary between the two countries in the Gulf of Thailand, of 24 Oct. 1979. See PRESCOTT, op.cit.n.2 at 92-94.

${ }_{10}$ Agreement on the delimitation of the maritime boundary between the two countries in the Gulf of Thailand, of 9 August 1997. See NGUYEN HONG THAO, "Vietnam's first maritime boundary agreement”, IBRU, Boundary and Security Bulletin, Vol.5 No. 3 (Autumn 1997) 74-79.
} 
islet stands 1.5 metres above sea level; it is uninhabited and has no economic significance of its own. According to Malaysia, this islet can have no effect on the maritime delimitation. In contrast, Thailand persists that Ko Losin does indeed have some impact. The equidistant lines as drawn by both sides have created an overlapping area. The disagreement led to a temporary solution. On 21 February 1979 a Memorandum of Understanding (MOU) on a joint development area was concluded. Lines indicating the two unilateral claims delimited the area under discussion: the extended claim by Thailand of 1973, and a 1979 claim by Malaysia. ${ }^{11}$ The gas reserves in the Thai-Malaysian Joint Development Area were estimated at the end of 1996 to be 6.5 trillion cubic feet. ${ }^{12}$

There is also an overlapping area of $2,500 \mathrm{~km}^{2}$ resulting from claims by Malaysia and Vietnam. On 9 June 1971, South Vietnam opened the bidding with a claim to the seabed, delimited by the median line between the coastal islands belonging, respectively, to Malaysia and to Vietnam. In 1979, the Malaysian authorities published charts showing the Malaysian claim to the continental shelf, with an outer limit as determined by the median line between the Malaysian island of Redang and the Vietnamese cape Camau, with no consideration of the Vietnamese coastal islands.

Since 1986 Malaysia has intensified hydrocarbon development in the Gulf. Having drilled more than 300 exploratory wells, ESSO (USA) estimates that the area may have reserves of about two billion barrels of oil and 20,000 trillion cubic feet of gas. Malaysia has signed three petroleum contracts with foreign enterprises, whose areas overlap the area claimed by Vietnam. The blocks (PM 8 and PM 5) granted to ESSO (USA) have overlapping areas of 200 square kilometres and 300 square kilometres respectively. The contract signed with HAMILTON (USA and Australia) has 1440 square kilometres of overlap with a Vietnamese block (block 46). Besides, mention may be made of the area of 800 square kilometres claimed by three countries Vietnam, Malaysia and Thailand - in the Thai-Malaysian Joint Development Area (JDA). In May 1991, HAMILTON announced that the test of Bunga Orkid-1 in the PM-3 bloc showed a rate of 4,400 barrels of petroleum a day. In the Malaysian-Vietnamese overlapping area the gas reserves were estimated to be 1.1 trillion cubic feet. ${ }^{13}$ Protests arose immediately from the Vietnamese authorities. On 30 May 1991, a note was sent to the Malaysian Foreign Ministry reaffirming that the friendship and the cooperative spirit between the two countries did not allow either country unilaterally to grant to a third party the right to explore and exploit petroleum in the overlapping area. Vietnam was ready to negotiate with Malaysia on the subject of the delimitation of the continental shelf between the two countries on the basis

\footnotetext{
11 KRIANGSAK KITTICHAISAREE, The law of the sea and maritime boundary delimitation in Southeast Asia (Oxford University Press, Singapore, 1987) Appendix 6.

12 PRESCOTT, op.cit.n.2 at 12.

13 Id. at 14.
} 
of respecting each other's sovereignty and mutual interests, in conformity with international law and practice. As a consequence, all projects of petroleum exploration and exploitation carried out by PETRONAS (the national petroleum company of Malaysia) were suspended pending the result of the negotiations with the Vietnamese side.

Geologically, the overlapping area is located in the Malay basin, 1,000 kilometres in length and 300 kilometres in breadth. With a sediment thickness of between eight and nine kilometres, the basin holds the promise of favourable oil findings. HAMILTON's tests confirmed these prospects. It pushed the two parties rapidly to find a mutually acceptable solution. During an official visit by the Vietnamese prime minister VO VAN KIET to Kuala Lumpur in early 1992, it was agreed to start negotiations on the delimitation of the continental shelf. ${ }^{14}$ The first round of Malaysian-Vietnamese negotiations, held in early June 1992 in Kuala Lumpur, were successful and resulted in the MOU of 5 June $1992 .{ }^{15}$ In it the two sides agreed on a "defined area", located off the northeast coast of West Malaysia and off the southwest coast of Vietnam, falling under the overlapping claims of the two states. In this area the two parties agreed to explore and exploit petroleum in that area in accordance with a joint development model, in a spirit of understanding and cooperation, pending and without prejudice to a definitive delimitation. The arrangement excluded any area simultaneously claimed by a third country.

The "defined area" is very long (more than 100 miles) but narrow (less than ten miles). As a result of its narrowness, any petroleum field discovered will probably only partially be located in the area. This explains why the two parties rapidly arrived at a practical arrangement: the joint development of the "defined area". Where a petroleum field is located partly within and partly outside the "defined area" of the continental shelf of Malaysia and Vietnam, both parties shall arrive at mutually acceptable terms for the exploration and exploitation of petroleum therein. Malaysia and Vietnam agreed to assign PETRONAS and PETROVIETNAM, respectively, to undertake, on their respective behalves, the exploration and exploitation of petroleum in the "defined area" and to enter into appropriate commercial arrangements. The Commercial Arrangement of 25 August 1993 between PETRONAS and PETROVIETNAM showed a new step in the development of models of cooperation in comparison with the Thai-Malaysian MOU of 1979 on joint development.

\footnotetext{
14 Nhan Dan Daily of 25 January 1992.

is Text in J.R.V.PRESCOTT, The Gulf of Thailand : maritime limits to conflict and cooperation, (MIMA, 1998) at 96-100.
} 


\section{COMPARISON BETWEEN THE THAI-MALAYSIAN MOU OF 1979 AND THE VIETNAMESE-MALAYSIAN MOU OF 1992}

The Thai-Malaysian MOU of 1979 and the Vietnamese-Malaysian MOU of 1992 have the identical purpose of introducing a system of joint development of petroleum resources by the two parties concerned. Both consist of eight articles. Article I of both instruments defines the contours of the joint development areas. The Thai-Malaysian area of 7,300 square miles is delimited by seven points. The southern boundary of the area deviates from the equidistant line between the coastal lines of the two countries so that the area overlaps the tripartite Vietnamese-Thai-Malaysian area. The VietnameseMalaysian joint development area is delimited by a series of straight lines linking six points. The coordinates of these points are determined in Article I of the respective MOU.

The first principle to be found in both MOUs concerns the management of resources in the joint development areas. The Thai-Malaysian MOU established the Malaysian-Thai Authority (referred to as the Joint Authority) for the purpose of the exploration and exploitation of non-living natural resources of the seabed and subsoil in the overlapping area for a period of fifty years from the date of entry into force of the MOU. The Joint Authority consists of two co-chairmen, one from each country, and an equal number of members from each country. An MOU dealing specifically with the constitution and establishment of the Joint Authority was signed by the two countries on 30 May 1990. In the case of Vietnam and Malaysia, another model of management was opted for. Article III of the MOU of 1992 stipulated that Malaysia and Vietnam agreed to assign PETRONAS and PETROVIETNAM, respectively, to undertake, each on its own respective behalf, the exploration and exploitation of petroleum in the "defined area". For this purpose, PETRONAS and PETROVIETNAM were to enter into a commercial arrangement, the terms and conditions of which would be subject to the approval of the respective governments. The arrangement, concluded on 25 August 1993, provided for the establishment of an eight-member Co-ordination Committee on the basis of equal representation, with each of the respective national oil companies appointing four members. This Committee was to issue policy guidelines for the management of petroleum operations and to operate on the basis of unanimity. In contrast to the Thai-Malaysian model, the chairmanship of the Committee would alternate between the parties every two years. As to existing petroleum sharing contracts (PSC) signed by Malaysia before the conclusion of the arrangement, the two parties agreed that the contractors concerned would continue carrying out their operations in the Defined Area as provided under the PSCs. This was a compromise from the Vietnamese side, both for technical and economic reasons and in order to speed up optimum exploration and exploitation in the arrangement area. Nevertheless, the PSC contractors would have duly to inform both Parties about the progress of their operations and any amendments and changes of, and supplements 
to, the PSCs would be subject to prior agreement of both Parties. The validity of the existing PSCs would not adversely affect the equal sharing of economic benefits between both Parties. Significantly, PETROVIETNAM would authorize PETRONAS to manage the petroleum operations under the existing PSCs, under the broad direction of the Co-ordination Committee in accordance with the provisions of the MOU, the commercial arrangement, and the PSCs.

We can see that, in respect of the management of the joint development, the Vietnamese-Malaysian model appears more flexible than the ThaiMalaysian model. The Co-ordination Committee is appointed by national petroleum companies rather than directly by the governments as in the ThaiMalaysian model. Any dispute or disagreement arising from or in connection with commercial and petroleum operations are to be settled by the two national companies under the broad direction of the Co-ordination Committee. Any resolution or decision reached by this Committee is to be consistent with the friendly nature, prudence and modern practice of the international petroleum industry. Disputes or disagreements that cannot be settled amicably by the Co-ordination Committee are to be submitted to the governments of Malaysia and Vietnam for settlement. Thus the governments would not interfere too intrusively in the business operations. The model also shows the good intention of the Vietnamese party to promote existing petroleum operations. By refraining from demands for changes in existing Malaysian PSCs, the Vietnamese party agreed to undertake joint activities by giving complete responsibility to PETRONAS.

The second principle contained in both MOUs is the equal sharing of all costs, expenses, liabilities and benefits resulting from the petroleum activities in the joint development areas under the MOUs and other, subsidiary, arrangements. However, the implementation of the principle in each of the two cases is different. In the Thai-Malaysian model, all costs incurred and benefits derived by the Joint Authority from activities carried out in the joint development area shall equally be borne and shared by both parties. In the Vietnamese-Malaysian model, on the other hand, while the two parties also assume and bear equally all costs and benefits carried out under the commercial arrangements, the system of joint management is replaced by a total mandate granted to PETRONAS, which undertakes all PSC operations in the Defined Area under the direction of the Co-ordination Committee. PETRONAS carries out all joint development operations and remits to PETROVIETNAM its equal share of the net revenue free of any taxes, levies or duties. Consequently, the law applicable to petroleum operations in the joint development area is the petroleum law of Malaysia. Vietnam agreed to this arrangement in order to avoid interfering with the existing PSCs relating to the Defined Area and because it did not yet have a petroleum law at that time. ${ }^{16}$

16 Text in J.R.V.PRESCOTT, The Gulf of Thailand: maritime limits to conflict and cooperation (MIMA, 1998) at 96-100.

16 Vietnamese Petroleum Law was approved on 6 July 1993. 
Article IV of the Thai-Malaysian MOU affirms that the national authorities of either party are entitled to exercise rights relating to fishing, navigation, hydrographic and oceanographic surveys, prevention and control of marine pollution and other similar matters in the joint development area, and that these rights shall be recognized by the Joint Authority. The MOU also establishes a criminal jurisdiction line, which divides the joint development area into two unequal parts: 930 square miles and 1,100 square miles for Malaysia and Thailand respectively. ${ }^{17}$ The line is not meant to serve as the boundary line of the continental shelves of the two countries in the joint development area and is not in any way prejudicial to the sovereign rights of either Party in the joint development area. The above provisions show that, beside the issue of petroleum resources, the Thai and Malaysian authorities have also to face problems of illegal fishing and similar matters in the joint development area. In contrast, Vietnamese-Malaysian relations are less severely affected by the fishing issue because of the abundance of living resources and the large maritime spaces that are available to both countries. This explains why the Vietnamese-Malaysian MOU does not deal with matters other than the petroleum activities in the joint development area.

The third principle relating to the joint development areas concerns the matter of unity of deposit. Both MOUs envisage the situation of a single geographical petroleum or natural gas structure or field, or other mineral deposit of whatever character, extending beyond the limits of the joint development area. In this situation, the parties concerned shall share all relevant information and shall seek to reach agreement regarding the manner in which the structure, field or deposit will be most effectively exploited. For example, Article II of the Vietnamese-Malaysian MOU [reads]:

"Where a petroleum field is located partly in the Defined Area and partly outside that area in the continental shelf of Malaysia or the Socialist Republic of Vietnam, as the case may be, both parties shall arrive at mutually acceptable terms for the exploration and exploitation of petroleum therein".

With regard to the issue of dispute settlement, both MOUs prescribe that any difference or dispute arising out of the interpretation or implementation of the provisions of the MOU shall be settled peacefully by consultation or negotiation between the two parties on the basic of good neighborliness and in conformity with international law.

The Thai-Malaysian MOU has a validity of fifty years. If no satisfactory solution is found for the problem of delimitation of the boundary of the continental shelf within this fifty-year period, the Joint Authority will continue to function indefinitely. The Vietnamese-Malaysian MOU, on the other hand, does not specify any term. The commercial arrangement concluded by the

17 PRESCOTT, op.cit.n.2 at 33. 
two national petroleum companies states that it remains effective until either (i) the MOU expires, or (ii) the arrangement is terminated by agreement of both parties and/or both governments, or (iii) the termination of the PSC.

While adhering to the same idea of institutional and organizational joint development in facing similar maritime issues in the same region, the ThaiMalaysian and the Vietnamese-Malaysian models are different and produce different results. The Thai-Malaysian MOU was signed in 1979 but the two parties exchanged their instruments of ratification only on 30 May 1990. Two contracts were concluded relating to their joint development area, one between PTTEP and PETRONAS Carigali, another between PETRONAS Carigali and Triton Oil, both contracts having come into effect only in early 1994. Apart from these contracts UNOCAL has been granted petroleum concessions for some areas in the Gulf. It took fifteen years for the Thai and Malaysian authorities to overcome legal obstacles in realizing their model. In the case of the Vietnamese-Malaysian model, after four years from the conclusion of the commercial arrangement, on 29 July 1997, the first petroleum was extracted from the Bunga Kekwa field. This event has marked the great success of this model of joint development in the Gulf.

\section{FROM THE THAI-MALAYSIAN MOU OF 1979 TO THE VIETNAMESE-MALAYSIAN MOU OF 1992: FACTORS IN THE SUCCESS OF AN ARRANGEMENT FOR JOINT DEVELOPMENT}

\subsection{Legal basis and the political will of the parties}

Cases of joint development can be found in areas both having or lacking determined boundaries, and in cases both involving and not involving conflicts. ${ }^{18}$ In the North Sea Continental Shelf cases, the International Court of Justice held: "[I]f ... the delimitation leaves to the Parties areas that overlap, these are to be divided between them in agreed proportions or failing agreement, equally, unless they decide on a regime of joint jurisdiction, use, or exploitation for the zone of overlap or any part of them". 19

A legal basis for joint development can be found in paragraph 3 of Articles 74 and 83 of UNCLOS 1982:

18 Fox, op.cit.n.1; L.LUCCHINI and M.VoElCKEL, Droit de la mer, Vol.2 part 1: Délimitation (Pedone) 115-118; T. ONORATO and MARK J.VALENCIA, "International cooperation for petroleum development: the Timor Gap Treaty”, Foreign Investment Law Journal vol. 5, n 1, (Spring 1990), p. $59-78$.

MARK J.VALENCIA, "Taming troubled waters: joint development of oil and mineral resources in overlapping claim areas", San Diego Law Review vol. 23, n 3 (1986), 343-351.

19 North Sea Continental Shelf Cases, judgement of 20 February 1969, ICJ Rep. 1969: 3. 
"Pending agreement as provided for in paragraph 1, the States concerned, in a spirit of understanding and co-operation, shall make every effort to enter into provisional arrangements of a practical nature and, during this transitional period, not to jeopardize or hamper the reaching of the final agreement. Such arrangements shall be without prejudice to the final delimitation".

The Convention on the Law of the Sea does not define exactly what the "provisional arrangements of a practical nature" to be taken are. In practice, the creation of a joint development area constitutes an effective provisional arrangement permitting countries to overcome their territorial disputes and facilitating the exploitation of natural resources in the transitional period. The countries concerned shall negotiate in good faith to reach "provisional arrangements of a practical nature". They are free to choose any mode of arrangement for the overlapping areas in conformity with international law. While preventing any prejudicial exploitation and avoiding any waste of non-utilization of natural resources, the application of a joint development regime for the whole or a portion of an area of overlap constitutes an attractive and agreeable measure pending a final delimitation. Significantly, the MOUs relating to the Gulf of Thailand were not based on conventional international law. They were concluded before UNCLOS entered into force (on 16 November 1994). It could be asked whether these MOUs find their legal foundation in customary international law.

ONORATO argues that joint development may constitute a rule of customary international law, on the basis of three considerations: first, a state may not unilaterally exploit a common international petroleum deposit despite timely objections raised by another interested state; second, the method of exploitation of a such deposit must be agreed on by the states involved; third, these states should enter into good faith negotiations in order to arrive at an agreement or at least at a provisional arrangement until a final agreement is reached. ${ }^{20}$ Quoting the ICJ opinion of 1982 in the Tunisian and Libyan continental shelf case and citing state practice in 14 cases, conventional international law, general principles of law, and principles of soft law, GAO ZHIGUO emphasizes that joint development is a binding rule of international law. ${ }^{21}$ Here, in our opinion, one should be prudent. Firstly, international law indeed prescribes states to conduct negotiations in a spirit of good faith with the aim of reaching an agreement or, at least, a "provisional arrangement of a practical nature" pending a final agreement. This signifies that a joint development solution serves the purpose only of a provisional arrangement.

\footnotetext{
${ }^{20}$ T.ONORATO, "Apportionment of an international common petroleum deposit: a reprise", 26 ICLQ (1977) 324.

21 ZHIGUO GAO, "The legal concept and aspects of joint development in international law", 13 Ocean Yearbook (1998) 123: "Joint development is an emerging rule of customary international law, or at least a principle of soft law, under which unconsented, unilateral, and arbitrary development of shared resources in a disputed area between states is prohibited and unacceptable".
} 
Thus, the option of a joint development arrangement is not obligatory whereas the pursuit of a final solution is. The concept of joint development can indeed be found in state practice, in conventional international law and in international jurisprudence. However, there is no uniform definition of "joint development" in conventional international law and various definitions are to be found in legal literature. ${ }^{22}$ Secondly, the number of cases of joint development arrangements is not sufficient for an opinio juris to have emerged on the matter. A maritime delimitation is always the principal and final aim of the states concerned and joint development is only a temporary solution. It appears that there is in fact no rule of international law prescribing joint development.

In the Gulf of Thailand cases, the states in question have preferred to express their common will in the form of a "Memorandum of Understanding" rather than in an "agreement". Although the MOU is undoubtedly one of the various possible forms of an international agreement, including, if the parties so wish, the stages of signature and ratification, it seems to offer a way of expressing a state's commitment at a lower level than that of a treaty. If we examine the contents of the MOUs concerned, we shall see that they do not settle all aspects of the existing disagreement; they manifest only the will of the states concerned to establish a joint development area by way of provisional solution to bridge their existing differences on the delimitation issue. The Vietnamese-Malaysian MOU seems to be more flexible when it delegates the responsibility of negotiating the details of the management of petroleum activities in the Defined Area to the respective petroleum companies. It shows the two countries' prudence and it also shows that joint development is not a matter of obligation under customary international law. The arrangement was reached as a result of the political will and the economic demands of the countries concerned. Thailand and Malaysia wanted to reach an accommodation in the spirit of ASEAN and were prompted by the desire to promote petroleum exploration and exploitation in order to avoid the consequences of the 1974 oil crisis. The Memorandum of Understanding

22 There are several definitions of "joint development":

- 'there are two types of joint development schemes: one is the type in which boundary delimitation has been solved and the other is a regime of joint development with the boundary delimited' (M.MrYOSHI, "The basic concept of joint development of hydrocarbon resources on the continental shelf", 3 International Journal of Estuarine and Coastal Law (1988) 3).

- 'the cooperation between States with regard to the exploration for and exploitation of certain deposits, fields or accumulations of non-living resources which either extend across a boundary or lie in an area of overlapping claims' (R.LAGONI, Report on joint development of non-living resources in the exclusive economic zone (Warsaw Conference of the International Committee on the Exclusive Economic Zone, International Law Association, 1988) 2).

- 'JDZ will be considered as being an area where two or more States have, under international law, sovereign rights to explore and exploit the natural resources of the area and where the States concerned have agreed to engage in such exploration and exploitation under some form of common or joint arrangement' (CHURCHILL, loc.cit.n.1 at 55). 
between Vietnam and Malaysia came about smoothly because of the discovery of new petroleum structures and deposits and because of the changing political situation in the region, shifting from confrontation to dialogue. The long time that passed between signature and ratification of the Thai-Malaysian MOU shows clearly that the method of joint development is not the consequence of a rule of customary international law.

Finally, it is remarkable that joint development is not exclusively applied in cases of disputed areas. After an agreement on maritime delimitation was concluded by Thailand and Vietnam in 1997, the two countries continued to conduct joint management of natural resources in the delineated zone.

\subsection{Economic factors}

In the areas falling under claims of overlapping, it is generally difficult to reach an agreement on delimitation, which needs the necessary political will and sufficient time. That situation hampers foreign investment since no companies are prepared to take the risk of investing in the development of an area with an uncertain status. Apart from that, international law does not encourage unilateral exploration and exploitation in a disputed area. In such circumstances joint development can be an effective way to by-pass existing obstacles. The value of joint development lies in its ability to avoid disputes and act in a way that favours economic development. Thailand was in favour of concluding a Memorandum of Understanding with Malaysia in 1979, because of Thailand's heavy dependence on oil imports, much greater than those of Malaysia. However, in its dispute with Vietnam, Thailand preferred to concentrate on a definitive solution by way of delimitation rather than aiming for joint development. Finally, Vietnam and Malaysia rapidly reached an accord on joint development because of their respective economic interests in the discovered deposits.

Knowledge of the availability of natural resources at the seabed and subsoil of the area concerned plays an important role in finding a solution for the dispute. The less knowledge is available, the easier it is to reach a compromise. The discovery of new structures or deposits causes the States concerned to push their claims to the maximum extent. On the other hand, joint development implies a solution of "no gain no loss" and seems to exert a calming influence on the states concerned. The equal share of costs and benefits guarantees also equal rights for the parties. When the prospects for the full exploitation of the natural resources are present, the issue of delimitation is not a difficult subject of negotiation.

Although joint development is a useful tool in resolving disputes between states with overlapping legal claims to the same area, the practice is not simple. A joint development arrangement is temporary in nature and is limited to its economic objective. If it does not achieve positive results, it should be abolished. The South Korea-Japan joint development scheme is an example. 
Signed in 1974 , the agreement was to apply to an area of 80,000 square kilometres and was projected for 50 years from 1978. However, the lack of economically relevant output hampers the agreement's implementation.

\subsection{Other factors}

Another important factor involves co-operation and a good relationship between the states concerned. The admission of Vietnam into ASEAN has contributed in creating favorable conditions for reaching a solution of the delimitation issue by furthering co-operation in the spirit of ASEAN between states in the region.

Joint development can be a positive device only if it is linked to a convenient management model. The Thai-Malaysian MOU of 1979 envisaged the establishment of a Joint Authority to manage the activities in the joint development area. However, the two parties could not reach a common position in determining its powers, which was the reason why the Joint Authority came into force only in 1994, fifteen years after the signature of the MOU.

Good management of joint development depends also on the dimensions of the joint development area. If the area is small, the states concerned can arrive at a common view on the joint development of the whole area more easily than, for example, in the case of the Vietnamese-Malaysian joint development area. On the other hand, a large joint development area such as the South Korean-Japanese area of 1974 had to be divided into nine smaller sub-zones in 1987 in order to attract foreign investment.

If the number of countries involved is small, an agreement on joint development can be reached relatively easily. That is why all existing agreements of joint development in the world are bilateral in nature. The tripartite overlapping area of 800 square kilometres involving Thailand, Vietnam, and Malaysia, located inside the Thai-Malaysian joint development area of 1979, will be the first multilateral joint development arrangement in the world. The negotiations held by the three countries since 1999 have resulted in an agreement in principle on the joint development for the tripartite area. The area is delimited by the line showing the Vietnamese claim of 1971 , and the northern boundary of the Thai-Malaysian joint development area of 1979 . All non-living resources of the tripartite area should be equally divided between the parties. The parties will continue to discuss technical questions such as organization and the choice of operators.

Joint development usually deals with petroleum exploration and exploitation. However, the approach can also be applied to cases involving disputes over an exclusive economic zone or over fishing management, as evidenced by: the Papua New Guinea-Australia agreement of 18 December 1978; the Iceland-Norway (Jan Mayen) agreement of 22 October 1981; the IndonesiaAustralia (Timor Gap) treaty of 11 December 1989; the joint statements of 
1989 and 1990 on the Falkland Islands by the United Kingdom and Argentina; the Sino-Japanese agreement of 11 November 1997, the Sino-South Korea agreement of 2000 on the common fishery zones and the Sino-Vietnamese agreement of 2000 on fishing cooperation in the Beibu Gulf.

The joint development system has given rise to a series of problems about the applicable law, security, customs, taxation, share of costs and benefits, and environment. However, the management of natural resources in the joint development areas primarily raises the question of administration. This is the factor that deserves the utmost consideration in our quest for effective solutions.

\section{CONCLUSION}

The experience of joint development in the Gulf of Thailand shows that, assuming the existence of an adequate political will and spirit of good neighborliness, joint development offers a convenient solution for states dealing with maritime delimitation disputes, allowing them to bypass the principal issue temporarily and, pending a final delimitation, to allow the exploitation of natural resources on a provisional basis, thereby effecting some economic development. 